\title{
Opioid receptor affinity and selectivity effects of second residue and carboxy terminal residue variation in a cyclic disulfide-containing opioid tetrapeptide
}

\author{
DEBORAH L. HEYL ${ }^{1}$, JOHN R. OMNAAS ${ }^{1}$, KATARZYNA SOBCZYK-KOJIRO $^{1}$, FEDOR MEDZIHRADSKY ${ }^{2,3}$, \\ CHARLES B. SMITH ${ }^{3}$ and HENRY I. MOSBERG ${ }^{\prime}$ \\ College of Pharmacy', Department of Biological Chemistry.2 and Department of Pharmacology, \\ The University of Michigan, Ann Arbor, Michigan, USA
}

Received 20 February, accepted for publication 23 September 1990

\begin{abstract}
The previously described cyclic, delta opioid receptor-selective tetrapeptide H-Tyr-D-Cys-Phe-D-Pen-OH, where Pen, penicillamine, is $\beta, \beta$-dimethylcysteine, was modified at residues 2 and 4 by varying combinations of $\mathrm{D}$ - and L-Cys and D- and L-Pen, and effects on mu and delta opioid receptor binding affinities and on potency in the mouse vas deferens (MVD) smooth muscle assay were evaluated. A comparison was drawn between consequences of alterations in this series of analogs and those of analogous modifications in the related cyclic pentapeptide series which includes the highly delta receptor-selective [D-Pen $\left.{ }^{2}, \mathrm{D}-\mathrm{Pen}^{5}\right]_{\text {enke- }}$ phalin, DPDPE. Unlike effects observed in the cyclic pentapeptide series, the mu receptor binding affinities of the cyclic tetrapeptides are not dramatically influenced by substitution of Pen for Cys at residue 2 . Conversely, while binding of the pentapeptides is only slightly affected by alteration of the chirality of the carboxy-terminal residue, modification of stereochemistry at the carboxy terminus in the tetrapeptides critically alters binding behavior at both mu and delta sites. In contrast with the pentapeptide series, the tetrapeptides appear to be highly dependent upon primary sequence for binding and activity, as only the lead compound binds with high affinity to the delta site. Results suggest that the less flexible cyclic tetrapeptides, lacking the $\mathrm{Gly}^{3}$ residue, display more stringent structural requirements for binding and activity than do the corresponding cyclic pentapeptides.
\end{abstract}

Key words: conformational restriction; delta opioid receptor; disulfide bond; enkephalin analog; mu opioid receptor; opioids

Enkephalins, one class of endogenous opioid peptides, lend themselves well to the design, synthesis, and study of analogs upon which conformational limitations have been imposed. Evidence supports a model of receptor heterogeneity that accounts for some of the differences in the various effects of enkephalin analogs; three well-documented opioid receptor subtypes, designated $\mathrm{mu}$, delta, and kappa, may mediate different physiological events (I). It is ap-

Abbreviations recommended by IUPAC-IUB Commission of Biochemical Nomenclature have been used. Other abbreviations: Pen. penicillamine; DPDPE, [D-Pen ${ }^{2}$, D-Pen ${ }^{5}$-enkephalin: DPLPE. [DPen $^{2}$, L-Pen ${ }^{5}$ enkephalin; Boc, t-butyloxycarbonyl; RP-HPLC, reverse phase-high performance liquid chromatography; TFA, trifluoroacetic acid; MVD, mouse vas deferens; DADLE, [D-Ala? D-Leu ${ }^{5}$ enkephalin. parent that these opioid receptor subtypes differ in their conformational requirements for peptide ligand binding and that $\mathrm{mu}$ and delta receptors may differ in the relative spatial orientation of sites interacting with various peptide residues (2). Peptide analogs designed with the appropriate conformational constraints may, therefore, display selectivity as a result of the ability to adopt the conformation required for interaction at one receptor subtype but not another. This, in turn, may help to define molecular binding mechanisms and elucidate actions mediated by the respective receptor subtypes. Conformationally restricted analogs also can be expected to assume a more well-defined solution conformation than their flexible counterparts, and this can be more reliably extrapolated to the bioactive conformation at the receptor.

We have previously described (3-6) a series of 
conformationally restricted enkephalin analogs which have the general structure:

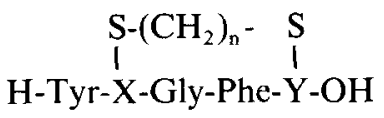

$\mathrm{X}=\mathrm{D}$-Cys or $\mathrm{D}-\mathrm{Pen}($ Pen $=$ penicillamine $=$ $\beta, \beta$-dimethylcysteine);

$\mathrm{Y}=\mathrm{D}$ - or L-Cys or D- or L-Pen;

$\mathrm{n}=0,1,2, \ldots$

This series is restricted not only by cyclization through the side chain sulfur atoms; rigidization is further effected by the Pen gem dimethyl groups (3). The disulfide analogs, most notably the bis-penicillamine compounds [D-Pen ${ }^{2}, \mathrm{D}-\mathrm{Pen}^{5}$ ] enkephalin (DPDPE) and $\left[\mathrm{D}-\mathrm{Pen}^{2}, \mathrm{~L}-\mathrm{Pen}^{5}\right]$ enkephalin (DPLPE), display a high degree of selectivity for the delta opioid receptor (4). Those analogs containing a single Pen residue tend to be less selective but more potent (5), and increasing the ring size via cyclization as the dithioether has been found to affect both delta receptor affinity and selectivity deleteriously (6).

To further explore structural requirements for the delta receptor selectivity displayed by the cyclic penicillamine-containing analogs, we investigated the binding affinity and selectivity and bioassay potency effects of ring contraction via a series of des-Gly ${ }^{3}$ disulfide- and dithioether-containing tetrapeptides of the general structure:

$$
\begin{gathered}
\mathrm{S}-\left(\mathrm{CH}_{2}\right)_{\mathrm{n}}-\mathrm{S} \\
1 \\
\text { H-Tyr-X-Phe- } \quad \mathrm{Y}-\mathrm{OH} \text { (or }-\mathrm{NH}_{2} \text { ) }
\end{gathered}
$$

$\mathrm{X}=\mathrm{D}$-Cys or D-Pen;

$\mathrm{Y}=\mathrm{D}-$ or L-Cys or D- or L-Pen;

$n=0,1,2, \ldots$

Among the analogs within this series with interesting binding profiles is one which exhibits similar delta receptor selectivity and 3.5-fold higher affinity than does DPDPE, itself (7). This compound, 1, is H-TyrD-Cys-Phe-D-Pen-OH, in which cyclization is via a disulfide bond (i.e. $\mathrm{n}=0$ ).

In order to further investigate this tetrapeptide series and to allow comparison with the cyclic disulfide-containing pentapeptide enkephalin analogs, we have prepared several analogs of $\mathbf{1}$ in which the effects of altering the order of the Cys and Pen residues, the number of Pen residues, and the chirality of the carboxy terminal residue were determined. These alterations of the cyclic parent peptide at the second residue and carboxy terminal position reveal some significant differences between the pentapeptide and tetrapeptide series.

\section{METHODS}

\section{Peptides}

Peptides were synthesized by standard solid phase methods similar to those previously described $(3,4,7$, 8 ), using chloromethylated polystyrene resin crosslinked with $1 \%$ divinylbenzene. Alpha-amino functions were t-butyloxycarbonyl (Boc) protected, and $p$-methylbenzyl protection was employed for the side chain sulfhydryl groups of Cys and Pen. Simultaneous deprotection and cleavage from the resin were accomplished by treatment with anhydrous hydrogen fluoride in the presence of either $10 \%$ anisole and $2 \%$ dithioethane or $5 \%$ cresol and $5 \% p$-thiocresol $(9)$ for $45 \mathrm{~min}$ at $0^{\circ}$. Prior to cyclization, the linear peptides were purified by reverse phase-high performance liquid chromatography (RP-HPLC) on a Vydac $218 \mathrm{TP}$ C- 18 column $(2.5 \times 22 \mathrm{~cm})$ using the solvent system $0.1 \%$ trifluoroacetic acid (TFA) in water $/ 0.1 \%$ TFA in acetonitrile, by a gradient of $10-50 \%$ organic component in $40 \mathrm{~min}$. Cyclization to disulfide analogs was accomplished by treatment of an aqueous solution ( $\mathrm{pH} 8.5$ ) of the free sulfhydryl-containing species with $\mathrm{K}_{3} \mathrm{Fe}(\mathrm{CN})_{6}$ (4). The oxidation reaction was allowed to continue until analytical HPLC indicated the disappearance of the free sulfhydryl containing species (ca. $2 \mathrm{~h}$ ). Cyclized peptides were purified by RP-HPLC as described above and lyophilized.

Tyr-D-Cys-Phe-D-Pen (1). The compound was synthesized as described previously (7). A $1.0 \mathrm{~g}$ sample of the precursor, resin bound peptide, Boc-Tyr-D-Cys(SpMeBzl)-Phe-D-Pen(S-pMeBzl)-resin, was treated with $10 \mathrm{~mL}$ of anhydrous $\mathrm{HF}$ in the presence of $1 \mathrm{~mL}$ anisole and $0.2 \mathrm{~mL}$ dithioethane at $0^{\circ}$ for $45 \mathrm{~min}$. After removal of HF under vacuum, the resin was extracted with $15 \mathrm{~mL}$ of a 9:1 mixture of dimethyl formamide/ $80 \%$ acetic acid. The filtrate was diluted with $135 \mathrm{~mL}$ of $0.1 \%$ aqueous TFA and subjected to semipreparative RP-HPLC as described above, which yielded, after lyophilization, $67.9 \mathrm{mg}$ of pure, linear, free sulfhydryl-containing peptide, Tyr-D-Cys(SH)Phe-D-Pen(SH)OH. Approximately $30 \mathrm{mg}$ of this free sulfhydryl-containing peptide was subjected to oxidation as described above, giving, after RP-HPLC, $7.8 \mathrm{mg}$ of title peptide, 1 .

Tyr-D-Cys-Phe-L-PenOH (2). The title compound was prepared by the same methods as described for 1 . HF treatment $(12 \mathrm{~mL} \mathrm{HF}, 0.24 \mathrm{~mL}$ dithioethane, $1.2 \mathrm{~mL}$ anisole) of $1.2 \mathrm{~g}$ of the precursor, resin-bound peptide, BocTyr-D-Cys(S-pMeBzl)-Phe-L-Pen(SpMeBzl)-resin, yielded, after extraction, semipreparative RP-HPLC, and lyophilization, $95.3 \mathrm{mg}$ of free sulfhydryl-containing peptide, Tyr-D-Cys(SH)Phe-L-Pen(SH)OH. A $30.5 \mathrm{mg}$ sample of this peptide was oxidized to yield, after RP-HPLC purification, $20.6 \mathrm{mg}$ of the title peptide, 2 . 
Tyr-D-Pen-Phe-D-PenOH (3). The title peptide was prepared by the same methods as described for 1 . HF treatment $(18 \mathrm{~mL} \mathrm{HF}, 0.37 \mathrm{~mL}$ dithioethane, $1.8 \mathrm{~mL}$ anisole) of $1.84 \mathrm{~g}$ of the precursor, resin-bound peptide, BocTyr-D-Pen(S-pMeBzl)-Phe-D-Pen(SpMeBzl)-resin, yielded, after extraction, semipreparative RP-HPLC, and lyophilization, $162 \mathrm{mg}$ of free sulfhydryl-containing peptide, Tyr-D-Pen(SH)Phe-D-Pen(SH)OH. A $31 \mathrm{mg}$ sample of this peptide was oxidized to yield, after RP-HPLC purification, $12 \mathrm{mg}$ of the title peptide, 3 .

Tyr-D-Pen-Phe-L-PenOH (4). The title peptide was prepared by the same methods as described for 1 . HF treatment $(15 \mathrm{~mL} \mathrm{HF}, 0.3 \mathrm{~mL}$ dithioethane, $1.5 \mathrm{~mL}$ anisole) of $1.53 \mathrm{~g}$ of the precursor, resin-bound peptide, BocTyr-D-Pen(S-pMeBzl)-Phe-L-Pen(SpMeBzl)-resin, yielded, after extraction, semipreparative RP-HPLC, and lyophilization, $124 \mathrm{mg}$ of free sulfhydryl-containing peptide, Tyr-D-Pen(SH)Phe-L-Pen(SH)OH. A $27.2 \mathrm{mg}$ sample of this peptide was oxidized to yield, after RP-HPLC purification, $7.7 \mathrm{mg}$ of the title peptide, 4 .

Tyr-D-Pen-PheD-CySOH (5). The precursor, resin bound peptide, BocTyr-D-Pen(S-pMeBzl)-Phe-DCys(S-pMeBzl)-resin, was prepared by the same methods as described for 1 . A $2.0 \mathrm{~g}$ sample of peptide resin was treated with $18 \mathrm{~mL}$ anhydrous $\mathrm{HF}$ containing $1 \mathrm{~g} p$-cresol and $1 \mathrm{~g} p$-thiocresol at $0^{\circ}$ for $45 \mathrm{~min}$. After removal of HF, extraction, and RP-HPLC, as described above, $202 \mathrm{mg}$ of pure, free sulfhydrylcontaining peptide, Tyr-D-Pen(SH)-Phe-D-Cys $\mathrm{SH}) \mathrm{OH}$, was obtained. A $28 \mathrm{mg}$ sample of this peptide was subjected to oxidation, as described above, yielding after RP-HPLC purification, $7.2 \mathrm{mg}$ of the title peptide, 5 .

Tyr-D-Pen-Phe-L-Cys $O H$ (6). The title peptide was prepared by the same methods described for 5 . HF treatment (18 mL HF, $1 \mathrm{~g} p$-cresol, $1 \mathrm{~g} p$-thiocresol) of $2.0 \mathrm{~g}$ of precursor peptide resin, BocTyr-D-Pen(SpMeBzl)-Phe-L-Cys(S-pMeBzl)-resin, yielded after purification, $165 \mathrm{mg}$ of free sulfhydryl-containing peptide Tyr-D-Pen(SH)-Phe-L-Cys(SH)OH. A $28 \mathrm{mg}$ sample of this peptide was subjected to oxidation, as described above, yielding after RP-HPLC purification, $7.2 \mathrm{mg}$ of the title peptide 6 .

\section{Peptide analysis}

Peptide purity and structure confirmation were established for all newly reported peptides using a combination of methods. Purity was assessed by subjecting each peptide to thin-layer chromatography (TLC) on silica plates in four separate solvent systems (all solvent ratios are volume:volume): A: n-butanol: acetic acid:water (4:1:5, organic component only); B: n-butanol:water (containing 3.5\% acetic acid and $1.5 \%$ pyridine $)(1: 1$, organic component only); $\mathrm{C}: \mathrm{n}$ butanol:pyridine:acetic acid:water (15:10:3:12); and D: n-amyl alcohol:pyridine:water (7:7:6). For each newly reported peptide all methods of visualization (ninhydrin, ultraviolet absorption, and iodine vapor) detected a single spot after TLC in each solvent system. Final product purity was also assessed by analytical RP-HPLC on a Vydac C-18 column (catalog number $218 \mathrm{TP} 54 ; 4.6 \mathrm{~mm} \times 250 \mathrm{~mm}$ ) monitored at $230 \mathrm{~nm}$ and $280 \mathrm{~nm}$ and analyzed with Waters Maxima 820 software. The solvents, which were prepared from HPLC grade chemicals were A: $0.1 \%$ TFA $(w / v)$ in water and B: $0.1 \%$ TFA $(w / v)$ in acetonitrile. A linear gradient of $0 \% \mathrm{~B}$ to $70 \% \mathrm{~B}$ in $70 \mathrm{~min}$ at a flow rate of $1 \mathrm{~mL} / \mathrm{min}$ was employed. Peaks which also appeared in chromatograms in which no peptide was injected were considered to be artifacts and were ignored. Peptide purity was then estimated by peak integration at each wavelength. The resulting purity estimates ranged from $94.3 \%$ to $99.5 \%$.

Evidence from complementary methods was utilized to confirm the structures of the newly reported peptides. All peptides were subjected to fast atom bombardment-mass spectrometry, which in all cases yielded the appropriate molecular weights. Additionally, all peptides were examined in $1 \mathrm{D}$ and $2 \mathrm{D}{ }^{1} \mathrm{H}$ NMR experiments on an IBM WP270SY spectrometer and/or a GE GN500 spectrometer operating at $270 \mathrm{MHz}$ and $500 \mathrm{MHz}$, respectively. All peptides were minimally subjected to 2D COSY analysis to establish intraresidue connectivities. Diagnostic resonances arising from the methyl groups and $\alpha$ proton of penicillamine and the aromatic resonances of phenylalanine and tyrosine confirmed the presence of these residues. Analogs 1, 2,3, and 4, each of which contains a cysteine residue, display $\mathrm{NH}-\alpha \mathrm{CH}-\beta \mathrm{CH}_{2}$ connectivities consistent with the presence of this residue. No unaccounted for resonances were observed. Analogs 1, 2, and 3 were further subjected to 2D NOESY experiments to obtain primary sequences from interresidue NOE interactions. In each case the anticipated sequence was confirmed.

The presence or absence of free sulfhydryl groups was examined for each peptide before and after cyclization by testing with 5,5-dithiobis(2-nitrobenzoic acid)(10). In all cases the linear peptides purified prior to treatment with $\mathrm{K}_{3} \mathrm{Fe}(\mathrm{CN})_{6}$ were found to contain two sulfhydryl groups, while the purified, posttreatment peptides contained none.

Receptor binding assays. The binding assays, based on the displacement by the test compounds of radiolabeled sufentanil (mu ligand) or DPDPE (delta ligand) in cerebral membranes from rat brain, were performed as previously described $(11,12)$. Briefly, the 
assay mixture, containing membrane suspension in $50 \mathrm{~mm}$ Tris buffer ( $\mathrm{pH} 7.4$ ), $150 \mathrm{mM} \mathrm{NaCl}$, the radiolabeled ligand and the test compound, was incubated to reach binding equilibrium ( $40 \mathrm{~min}$ for assays using $0.5 \mathrm{nM}\left[{ }^{3} \mathrm{H}\right]$ sufentanil; $60 \mathrm{~min}$ for $\left.1.5 \mathrm{~nm}\left[{ }^{3} \mathrm{H}\right] \mathrm{DPDPE}\right)$ at $25^{\circ}$. Subsequently, the samples were rapidly filtered and the radioactivity on the filter determined by liquid scintillation counting. Inhibition of radiolabeled ligand binding by the test compound was computed from maximal specific binding, determined with an appropriate excess of unlabeled sufentanil or DPDPE. IC $_{50}$ values were obtained by linear regression from plots relating inhibition of the specific binding in probit units to the log of five different ligand concentrations. In every case the correlation coefficient, $r^{2}$, of the log-profit plot was higher than 0.96 .

Isolated mouse vas deferens (MVD) assays. The MVD assays were performed as previously described (13). Briefly, $1.5 \mathrm{~cm}$ vas deferens segments from male, albino ICR mice were suspended in organ baths which contained $30 \mathrm{~mL}$ of a modified Krebs' buffer $(118 \mathrm{~mm}$ $\mathrm{NaCl}, 4.75 \mathrm{~mm} \mathrm{KCl}, 2.54 \mathrm{~mm} \mathrm{CaCl}, 1.19 \mathrm{mM} \mathrm{MgSO}_{4}$, $1.19 \mathrm{~mm} \mathrm{KH} \mathrm{KO}_{4}, 11 \mathrm{~mm}$ glucose, $25 \mathrm{~mm} \mathrm{NaHCO} 3$, $0.3 \mathrm{~mm}$ pargyline $\mathrm{HCl}, 0.2 \mathrm{~mm}$ tyrosine, $0.1 \mathrm{~mm}$ ascorbic acid, and $0.03 \mathrm{~mm}$ sodium EDTA) saturated with $95 \% \mathrm{O}_{2}-5 \% \mathrm{CO}_{2}$ and kept at $37^{\circ}$. The segments were attached to strain gauge transducers and suspended between two platinum electrodes. After a 30 min equilibrium period, the segments were stimulated once every $10 \mathrm{~s}$ with pairs of pulses of $2 \mathrm{~ms}$ duration, $1 \mathrm{~ms}$ apart and at supramaximal voltage. Test compounds were evaluated for their ability to inhibit the electric- ally stimulated smooth muscle contractions in this preparation and complete concentration-effect relationships were determined. $\mathrm{IC}_{50}$ values were determined by probit analysis and values reported are the means of 3-9 determinations.

\section{RESULTS AND DISCUSSION}

Pharmacological data for the peptides under study are presented in Table 1, while Table 2 summarizes the physicochemical properties of the newly reported tetrapeptides. Evaluation of the data reveals several interesting contrasts between the cyclic pentapeptide and the cyclic tetrapeptide series. Table 1 provides the mu and delta opioid receptor binding affinities and the MVD agonist potencies of six cyclic tetrapeptides. Also presented in Table 1 are previously reported (3, 5) binding and MVD results for the corresponding pentapeptides. As indicated in Table 1, evaluation of tetrapeptide binding affinity employed $\left[{ }^{3} \mathrm{H}\right]$ sufentanil as the radiolabeled mu ligand and $\left[{ }^{3} \mathrm{H}\right] \mathrm{DPDPE}$ as the radiolabeled delta ligand, while the earlier data for the pentapeptides relied on the less selective $\left[{ }^{3} \mathrm{H}\right]$ naloxone and $\left[{ }^{3} \mathrm{H}\right] \mathrm{DADLE}$ ([D-Ala $\left.{ }^{2}, \mathrm{D}-\mathrm{Leu}^{5}\right]$ enkephalin) as the $\mathrm{mu}$ and delta radioligands, respectively. As a result, quantitative comparisons between the two series are unwarranted (although results observed for DPDPE using each pair of radiolabeled ligands are in reasonable agreement) and only relative effects of the same modification in the two series are considered.

In the pentapeptide series, replacement of $D^{-}$ penicillamine with $\mathrm{D}$-cysteine at the second residue $\left(1^{\prime}\right.$ vs $3^{\prime}, 2^{\prime}$ vs $4^{\prime}$ ) leads to an increase in MVD

TABLE 1

Opioid receptor binding profiles and $M V D$ potencies of cyclic tetrapeptides and pentapeptides

\begin{tabular}{|c|c|c|c|c|c|c|c|c|}
\hline $\begin{array}{c}\text { Compound } \\
\text { No. }\end{array}$ & Analog & {$\left[{ }^{3} \mathrm{H}\right] \mathrm{Suf}$} & \multicolumn{2}{|c|}{ Binding $\mathrm{IC}_{50}(\mathrm{nM})$} & {$\left[^{3}\right.$ H]DADLE } & \multicolumn{2}{|c|}{$\mathrm{IC}_{50}(\mu) / \mathrm{IC}_{50}(\delta)$} & $\begin{array}{l}\text { MVD IC } \\
\text { (nM) }\end{array}$ \\
\hline 1 & Tyr-D-Cys-Phe-D-PenOH & 1210 & 1.9 & - & - & 637 & & 4.6 \\
\hline $1^{\prime}$ & Tyr-D-Cys-Gly-Phe-D-PenOH ${ }^{\mathrm{a}}$ & - & - & 22 & 3.5 & & 6.3 & 0.13 \\
\hline 2 & Tyr-D-Cys-Phe-L-PenOH & 1500 & 56 & - & - & 27 & & 156 \\
\hline $\mathbf{2}^{\prime}$ & Tyr-D-Cys-Giy-Phe-z-PenOH ${ }^{a}$ & - & - & 53 & 5.4 & & 9.8 & 0.75 \\
\hline 3 & Tyr-D-Pen-Phe-D-PenOH & 6020 & 26.9 & - & - & 224 & & 114 \\
\hline \multirow[t]{2}{*}{$\mathbf{3}^{\prime}$} & Tyr-D-Pen-Gly-Phe-D-PenOH ${ }^{\mathrm{a}}$ (DPDPE) & -- & - & 2840 & 16.2 & & 175 & 2.19 \\
\hline & & 7720 & 6.4 & - & - & 1200 & & 5.5 \\
\hline 4 & Tyr-D-Pen-Phe-L-PenOH & 386 & 34.5 & - & - & 11.2 & & 154 \\
\hline $4^{\prime}$ & Tyr-D-Pen-Gly-Phe-L-PenOH ${ }^{a}$ & - & - & 3710 & 10 & & 371 & 2.50 \\
\hline 5 & Tyr-D-Pen-Phe-D-CysOH & 4180 & 61 & - & - & 69 & & 65 \\
\hline $5^{\prime}$ & Tyr-D-Pen-Gly-Phe-D-CysOH ${ }^{b}$ & - & - & 157 & 26 & & 6.0 & 6.27 \\
\hline 6 & Tyr-D-Pen-Phe-L-CysOH & 2160 & 35.5 & - & - & 61 & & 287 \\
\hline $\mathbf{6}^{\prime}$ & Tyr-D-Pen-Gly-Phe-L-CysOH ${ }^{b}$ & - & - & 178 & 11.7 & & 15.2 & 0.32 \\
\hline
\end{tabular}

Suf $=$ Sufentanil. Nal $=$ Naloxone. DADLE $=\left[\mathrm{D}-\mathrm{Ala}^{2}, \mathrm{D}-\mathrm{Leu}^{5}\right]$ enkephalin.

${ }^{\mathrm{a}}$ Values from ref. 5.

${ }^{b}$ Values from ref. 3.

${ }^{c} I_{C_{50}}$ (sufentanil)/IC so $_{50}$ (DPDE).

${ }^{d} \mathrm{IC}_{50}$ (naloxone)/IC $\mathrm{C}_{50}$ (DADLE). 
TABLE 2

Physicochemical properties of cyclic opioid tetrapeptides

\begin{tabular}{|c|c|c|c|c|c|c|c|}
\hline \multirow{2}{*}{$\begin{array}{l}\text { Compound } \\
\text { No. }\end{array}$} & \multirow[t]{2}{*}{ Analog } & \multicolumn{4}{|c|}{ TLC Rf ${ }^{\mathrm{a}}$} & \multirow{2}{*}{$\begin{array}{c}\mathrm{HPLC}^{\mathrm{b}} \\
\mathrm{k}^{\prime}\end{array}$} & \multirow{2}{*}{$\begin{array}{c}\text { Mol. wt. } \\
\text { FAB-MS (calc) }\end{array}$} \\
\hline & & A & B & $\mathrm{C}$ & $\mathrm{D}$ & & \\
\hline 1 & Tyr-D-Cys-Phe-D-PenOH & 0.75 & 0.68 & 0.83 & 0.75 & 8.6 & $560(560)$ \\
\hline 2 & Tyr-D-Cys-Phe-L-PenOH & 0.73 & 0.56 & 0.83 & 0.70 & 8.4 & $560(560)$ \\
\hline 3 & Tyr-D-Pen-Phe-D-PenOH & 0.81 & 0.75 & 0.83 & 0.72 & 10.0 & $588(588)$ \\
\hline 4 & Tyr-D-Pen-Phe-L-PenOH & 0.81 & 0.65 & 0.83 & 0.71 & 9.7 & $588(588)$ \\
\hline 5 & Tyr-D-Pen-Phe-D-CysOH & 0.78 & 0.83 & 0.82 & 0.73 & 8.3 & $560(560)$ \\
\hline 6 & Tyr-D-Pen-Phe-L-CysOH & 0.72 & 0.52 & 0.80 & 0.68 & 8.1 & $560(560)$ \\
\hline
\end{tabular}

${ }^{a} \mathrm{Rf}$ values for thin-layer chromatograms in solvent systems: A: $\mathrm{n}$-butanol:acetic acid:water $(4: 1: 5$, organic component only); $\mathrm{B}$ : $\mathrm{n}$ butanol:water (containing $3.5 \%$ acetic acid and $1.5 \%$ pyridine)(1:1. organic component only); $\mathrm{C}$ : n-butanol:pyridine:acetic acid:water (15:10:3:12); and D: n-amyl alcohol:pyridine:water (7:7:6).

${ }^{b} \mathbf{k}^{\prime}$ values for HPLC in solvent system of $0.1 \%(\mathrm{w} / \mathrm{v})$ TFA in water $/ 0.1 \%$ TFA $(w / v)$ in acetonitrile. A linear gradient of $0 \%$ to $70 \%$ acetonitrile component in $70 \mathrm{~min}$ at a flow rate of $1 \mathrm{~mL} / \mathrm{min}$ was employed.

potency as well as a slight improvement in delta receptor binding affinity. More notably, this alteration causes a significant enhancement in mu receptor binding affinity. Since NMR studies of both DPDPE $\left(3^{\prime}\right)$ and $\left[\mathrm{D}-\mathrm{Cys}^{2}, \mathrm{D}-\mathrm{Pen}^{5}\right]$ enkephalin $\left(\mathbf{1}^{\prime}\right)$ indicate that their conformations are similar (14), the differences in binding affinity are believed to result from adverse steric interactions between the D-Pen ${ }^{2} \beta$-methyl groups and the receptor binding site, especially the mu site (hence, the considerable delta-selectivity of DPDPE). Subsequent work with stereospecifically monomethylated D-Cys incorporated at the second residue of DPDPE has, in fact, revealed that it is the pro- $R$ methyl of the $\mathrm{D}-\mathrm{Pen}^{2}$ residue that plays the major role in the steric interference which is most pronounced at the mu receptor binding site, leading to the observed drastic decline in mu affinity (15). In the more compact tetrapeptide series, however, no consistent difference in binding affinity or MVD potency can be noted upon substitution of D-Pen for D-Cys at the second position. While it is obvious that 1 , which contains a D-Cys ${ }^{2}$ residue, displays higher MVD potency and higher binding affinity for both mu and delta receptors than does the corresponding D-Pen ${ }^{2}$ containing analog, $\mathbf{3}$, compounds $\mathbf{2}$ and $\mathbf{4}$ are equipotent in the MVD assay, and it is 4, with a D-Pen ${ }^{2}$ residue, that displays somewhat higher affinity for the mu opioid receptor.

Modification of the carboxy terminal residue chirality in the cyclic pentapeptide series causes only minor variation in the binding affinity and selectivity of these compounds, as can be noted by comparison of binding data for $\left[\mathrm{D}-\mathrm{Cys}^{2}, \mathrm{D}-\mathrm{Pen}^{5}\right]$ enkephalin $\left(1^{\prime}\right)$ vs $\left[\mathrm{D}-\mathrm{Cys} \mathrm{s}^{2}\right.$, L-Pen ${ }^{5}$ enkephalin $\left(\mathbf{2}^{\prime}\right)$, DPDPE (3') vs DPLPE $\left(\mathbf{4}^{\prime}\right)$, and $\left[\mathrm{D}-\mathrm{Pen}^{2}, \mathrm{D}-\mathrm{Cys}{ }^{5}\right]$ enkephalin $\left(5^{\prime}\right)$ vs $\left[\mathrm{D}-\mathrm{Pen}^{2}{ }^{2}\right.$ L$\mathrm{Cys}^{5}$ ]enkephalin $\left(6^{\prime}\right)$. Changes in binding behavior are more apparent in the tetrapeptide series, although no obvious correlation exists between mu or delta affinity and the chirality of the carboxy terminal residue.
Compounds 1 and 2 display similar mu affinity but differ in delta binding, the D-amino acid terminal analog 1 exhibiting a higher delta receptor affinity. Conversely, $\mathbf{3}$ and $\mathbf{4}$ bind with comparable affinity at the delta receptor but not at the mu receptor, the L-amino acid terminal analog 4 exhibiting higher affinity. A comparison of 5 and 6 reveals similar binding affinities of the two tetrapeptides to both mu and delta opioid receptors. Clearly, the binding behavior of these tetrapeptides is more sensitive than that of the pentapeptides to stereochemistry at the carboxy terminus. In contrast to the pentapeptide series, stereochemical variation of the carboxy terminal residue apparently alters the conformational relationship of this residue to the rest of the molecule in a manner which significantly influences receptor interactions.

With regard to MVD potency, those tetrapeptides possessing a carboxy terminal L-amino acid generally are less potent in the MVD assay than are the corresponding carboxy terminal D-amino acid-containing analogs. In fact, with the exception of $\mathbf{1}$, the potencies of all these tetrapeptides are rather low, an observation that does not hold for the analogous pentapeptides. Although mu, delta, and kappa opioid receptors can all mediate the observed inhibition of smooth muscle contraction in the MVD preparation (16), antagonist shift data (not shown) for all the tetrapeptides presented here indicate that it is the delta receptor which is primarily responsible for the observed MVD activity. In the presence of $100 \mathrm{nM}$ ICI-174864, a highly selective delta antagonist (17), or in the presence of the somewhat mu-selective antagonist, naltrexone (13), the concentration-effect curves of these analogs, like that of DPDPE, are shifted to the right to a similar extent. This is indicative of a delta receptor mediated action (13) and has been observed for other members of this series (7).

The presence of the $\beta, \beta$-gem dimethyl groups of Pen residues at the carboxy terminal amino acid position 
is detrimental to $\mathrm{mu}$ binding but does not affect delta binding in the pentapeptide series $\left(3^{\prime}\right.$ vs $5^{\prime}, 4^{\prime}$ vs $\left.6^{\prime}\right)$. Examination of data for the tetrapeptides $\mathbf{3}$ vs $\mathbf{5}$ and 4 vs 6, likewise, reveals no significant change in delta binding for this modification, while effects on mu affinity are observed in the latter pair, the carboxy terminal L-Pen-containing analog 4 exhibiting higher mu receptor affinity than the corresponding L-Cys terminal compound, 6 . MVD potency effects are variable in both series.

The compounds in the pentapeptide series manifest a range of binding affinities, but all bind reasonably well to delta receptors. In contrast, the binding behavior of the tetrapeptides appears to be much more dependent upon primary sequence, and this phenomenon is most pronounced at the delta site. Compounds 2-6 display similarly moderate affinity at delta receptors; compound $\mathbf{1}$, however, binds much more tightly. This fact also is supported by the MVD assay, since only 1 exhibits high potency.

The greater dependence upon primary sequence for activity in the tetrapeptides reflects the conformational consequence of eliminating the $\mathrm{Gly}^{3}$ residue, which is present in the pentapeptides. As we have suggested previously, the $\mathrm{Gly}^{3}$ residue may act as a flexible hinge in the cyclic pentapeptides, allowing all members of that series to adopt a favorable delta binding conformation (14). The exclusion of $\mathrm{Gly}^{3}$ in the tetrapeptides would be expected to cause greater molecular rigidity, and therefore, less ability for this conformational compensation. The result would be a more precise requirement for a particular primary sequence, as is indeed observed in this tetrapeptide series. This more restricted series thus offers a valuable opportunity for assessing the key structural and conformational features necessary for activity at both $\mathrm{mu}$ and delta opioid receptors. It should be noted that studies by Schiller and coworkers (18) on a related cyclic tetrapeptide series displaying mu receptor selectivity have led to a proposal that these tetrapeptides interact differently at mu receptors than do the corresponding pentapeptides. In particular, it has been proposed that the aromatic side chain of the $\mathrm{Phe}^{3}$ residue of these tetrapeptides binds to a different region of the mu receptor than does the corresponding aromatic ring of the $\mathrm{Phe}^{4}$ residue of the enkephalinlike pentapeptides. Our present tetrapeptide series will allow an examination of whether similar multiple binding modes might be indicated for delta receptor interactions.

\section{ACKNOWLEDGMENTS}

This work was supported by USPHS grants DA03910 (H.I.M.) and DA00254 (H.I.M., F.M., C.B.S.). D.H. is grateful for the support of a J.E. Emmanuel Scholarship, a Lilly Endowment Fellowship, The American Foundation for Pharmaceutical Education, and the National Institutes of Health (Training Grant FM07767). H.I.M. is a recipient of a Research Scientist Development Award from the National Institute on Drug Abuse (DA00118).

\section{REFERENCES}

1. Lord, J.A.H., Waterfield, A.A., Hughes, J. \& Kosterlitz, H.W. (1977) Nature 267, 495-499

2. Schiller, P.W. \& DiMaio, J. (1982) Nature 297, 74-76

3. Mosberg, H.I., Hruby, V.J., Hurst, R., Galligan, J.J., Burks, T.F. \& Yamamura, H.I. (1983) Life Sci. 32, 2656-2659

4. Mosberg, H.I., Hurst, R., Hruby, V.J., Gee, K., Yamamura, H.I., Galligan, J.J. \& Burks, T.F. (1983) Proc. Natl. Acad. Sci. 80, 5871-5874

5. Mosberg, H.I., Hurst, R., Hruby, V.J., Galligan, J.J., Burks, T.F., Gee, K. \& Yamamura, H.I. (1983) in Peptides: Structure and Function (Hruby, V.J. \& Rich, D.H., eds.), pp. 279-282, Pierce Chemical Co., Rockford, IL

6. Mosberg, H.I., Omnaas, J.R. \& Goldstein, A. (1987) Mol. Pharmacol. 31, 599-602

7. Mosberg, H.I., Omnaas, J.R., Medzihradsky, F. \& Smith, C.B. (1988) Life Sci. 43, 1013-1020

8. Mosberg, H.I. \& Omnaas, J.R. (1985) J. Am. Chem. Soc. 107, 2986-2987

9. Heath, W.F., Tam, J.P. \& Merrifield, R.B. (1986) Int. J. Peptide Protein Res. 28, 498-507

10. Ellman, G.L. (1959) Arch. Biochem. Biophys. 82, 70-77

11. Clark, M.J., Carter, B.D. \& Medzihradsky, F. (1988). European J. Pharmacol. 148, 343-35I

12. Medzihradsky, F., Dahistrom, P.J., Woods, J.H., Fischel, S.V. \& Mitsos, S.E. (1984) Life Sci. 34, 2129-2138

13. Smith, C.B. (1987) NIDA Research Monograph Series No. 76 . Problems of Drug Dependence 1986, pp. 288-294

14. Mosberg, H.I. (1987) Int. J. Peptide Protein Res. 29, 282-288

15. Mosberg, H.I., Haaseth, R.C., Ramalingam, K., Mansour, A., Akil, H. \& Woodard, R.W. (1988) Int. J. Peptide Protein Res. 32, 1-8

16. Smith, C.B., Bennett-Kelly, L. \& Woods, J.H. (1984) Neuropeptides 5, 161-164

17. Cotton, R., Giles, M.G., Miller, L., Shaw, J.S. \& Timms, D. (1984) European J. Pharmacol. 97, 331-332

18. Schiller, P.W. (1988) in Recent Progress in Chemistry and Biology of Centrally Acting Peptides (Dhawan, B.N. \& Rapaka, R.S., eds.), pp. 11-24

Address:

Henry I. Mosberg

College of Pharmacy

University of Michigan

Ann Arbor, MI 48109

USA 